\title{
Functions of silicon in plant drought stress responses
}

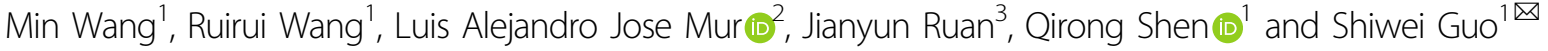

\begin{abstract}
Silicon (Si), the second most abundant element in Earth's crust, exerts beneficial effects on the growth and productivity of a variety of plant species under various environmental conditions. However, the benefits of Si and its importance to plants are controversial due to differences among the species, genotypes, and the environmental conditions. Although Si has been widely reported to alleviate plant drought stress in both the Si-accumulating and nonaccumulating plants, the underlying mechanisms through which Si improves plant water status and maintains water balance remain unclear. The aim of this review is to summarize the morphoanatomical, physiological, biochemical, and molecular processes that are involved in plant water status that are regulated by Si in response to drought stress, especially the integrated modulation of Si-triggered drought stress responses in Si accumulators and intermediate- and excluder-type plants. The key mechanisms influencing the ability of Si to mitigate the effects of drought stress include enhancing water uptake and transport, regulating stomatal behavior and transpirational water loss, accumulating solutes and osmoregulatory substances, and inducing plant defense- associated with signaling events, consequently maintaining whole-plant water balance. This study evaluates the ability of Si to maintain water balance under drought stress conditions and suggests future research that is needed to implement the use of Si in agriculture. Considering the complex relationships between $\mathrm{Si}$ and different plant species, genotypes, and the environment, detailed studies are needed to understand the interactions between Si and plant responses under stress conditions.
\end{abstract}

\section{Introduction}

Silicon ( $\mathrm{Si}$ ) is the second most abundant mineral element present in the soil, and silicon dioxide composes approximately $50-70 \%$ of the soil mass ${ }^{1-4}$. Si has various ecological functions, with complex roles in plant processes and in mediating interactions with the environment and other organisms ${ }^{5-7}$. $\mathrm{Si}$ accumulation varies greatly among plant species, ranging from 0.1 to $10 \%$ dry weight. Based on the Si content in tissues, plants can be classified as accumulator (e.g., rice, wheat, maize, and sorghum), intermediate (e.g., cucumber, bitter gourd, and melon), or excluder (e.g., tomato, potato, canola, and

\footnotetext{
Correspondence: Shiwei Guo (sguo@njau.edu.cn)

'Jiangsu Provincial Key Lab of Solid Organic Waste Utilization, Jiangsu

Collaborative Innovation Center of Solid Organic Wastes, The Key Laboratory of Plant Immunity, Nanjing Agricultural University, Nanjing 210095 Jiangsu, China

${ }^{2}$ Institute of Biological, Environmental and Rural Sciences, Aberystwyth

University, Aberystwyth SY23 3DA, UK

Full list of author information is available at the end of the article
}

lentil) types ${ }^{8,9}$. The differences are attributed to the different modes of Si uptake (active, passive, and rejective) ${ }^{10,11}$. In addition, these differences are largely due to the abilities of the roots of various plant species to absorb $\mathrm{Si}^{4}$, which is related to $\mathrm{Si}$ transporter expression and function. Below a $\mathrm{pH}$ of nine, $\mathrm{Si}$ is generally taken up by plant roots in the form of silicic acid $\left[\mathrm{Si}(\mathrm{OH})_{4}\right]$, an uncharged monomeric molecule ${ }^{4}$ that is dependent primarily on a specific Si influx transporter (Lsi1) and a specific efflux transporter (Lsi2). Another influx transporter, Lsi6, regulates the unloading of Si from the xylem to leaf tissues and further facilitates root-to-shoot translocation $^{4,12,13}$. In addition to $\mathrm{Si}$ taken up by roots, Si fertilizer can also be efficiently supplied to leaves to increase plant dry matter production ${ }^{14-17}$ and is absorbed mainly via cuticular pathways, stomata, and trichomes ${ }^{18}$. Foliar application of $\mathrm{Si}$-containing solutions is a viable alternative $\mathrm{Si}$ fertilization method to increase $\mathrm{Si}$ accumulation,

\section{(c) The Author(s) 2021}

(c) (i) Open Access This article is licensed under a Creative Commons Attribution 4.0 International License, which permits use, sharing, adaptation, distribution and reproduction in any medium or format, as long as you give appropriate credit to the original author(s) and the source, provide a link to the Creative Commons license, and indicate if changes were made. The images or other third party material in this article are included in the article's Creative Commons license, unless indicated otherwise in a credit line to the material. If material is not included in the article's Creative Commons license and your intended use is not permitted by statutory regulation or exceeds the permitted use, you will need to obtain permission directly from the copyright holder. To view a copy of this license, visit http://creativecommons.org/licenses/by/4.0/. 
especially for intermediate and $\mathrm{Si}$ nonaccumulator plants $^{15,16,19,20}$.

During their growth and development, plants are subjected to various environmental stresses. $\mathrm{Si}$ has been widely reported to enhance plant tolerance to various abiotic and biotic stresses, such as drought, salt, freezing, nutrient imbalance, radiation damage, metal toxicity, pests, and pathogens ${ }^{5,21-26}$. Drought, a recurring phenomenon with major impacts on both humans and natural ecosystems, is the most widespread climatic extreme that hinders primarily crop growth and productivity ${ }^{27}$. In this context, the alleviating effects of Si on drought stress has been observed in a wide variety of crop plants species, including both monocots (e.g., rice, wheat, maize, and sorghum) and dicots (e.g., tomato, cucumber, sunflower, soybean, cotton, mango, and canola $)^{28-38}$. Interestingly, $\mathrm{Si}$ has been shown to counteract the effects of drought stress in plant species that have a weakly ability to accumulate $\mathrm{Si}$ (Si excluders), such as tomato and canola. Additionally, wheat landraces that were high $\mathrm{Si}$ accumulators had higher levels of shoot Si compared to low accumulators, but no differences in growth or stress tolerance were observed underwater stress ${ }^{39}$. This suggests that the effects of Si are not proportional to its accumulation in plants and that a low amount of Si accumulation does not equate to poor function ${ }^{40}$. The role of $\mathrm{Si}$ in low Siaccumulating plants is attributed mainly to the biochemical function of $\mathrm{Si}$, while mechanical/physical barriers induced by $\mathrm{Si}$ deposition in high $\mathrm{Si}$-accumulating plants are important for the stress response ${ }^{7,32,41}$. For example, $\mathrm{Si}$ also was shown to induce resistance to bacterial wilt disease caused by Ralstonia solanacearum in $\mathrm{Si}$ nonaccumulating tomato plants, which was mediated mainly via signaling pathways, such as those involving ethylene (ET), jasmonic acid (JA), and/or reactive oxygen species (ROS) ${ }^{42}$.

Although $\mathrm{Si}$ is not considered an essential element for plants, it is well known to be beneficial for plant growth and development, especially under stress conditions ${ }^{2,5,43}$. Si stimulates seed germination in wheat, maize, lentil, and tomato under drought stress ${ }^{41,44-46}$, the effects of which are attributed to the increased antioxidant defense and decreased oxidative stress induced by $\mathrm{Si}^{41,47}$. During plant growth, $\mathrm{Si}$ has been found to increase plant biomass and grain yields of several crop species under drought stress $^{29,35,48,49}$, which is attributed to increases in total root length, surface area, and volume as well as increases in plant height, dry matter, panicle length, and tiller number ${ }^{28,48,50}$. Another important feature due to the possible role of $\mathrm{Si}$ is reducing spikelet sterility and subsequently increasing the grain yields of rice supplied with $\mathrm{Si}^{28,48,50}$.

Given the obvious benefits of $\mathrm{Si}$ on drought tolerance (Fig. 1), it may be expected that its process has been

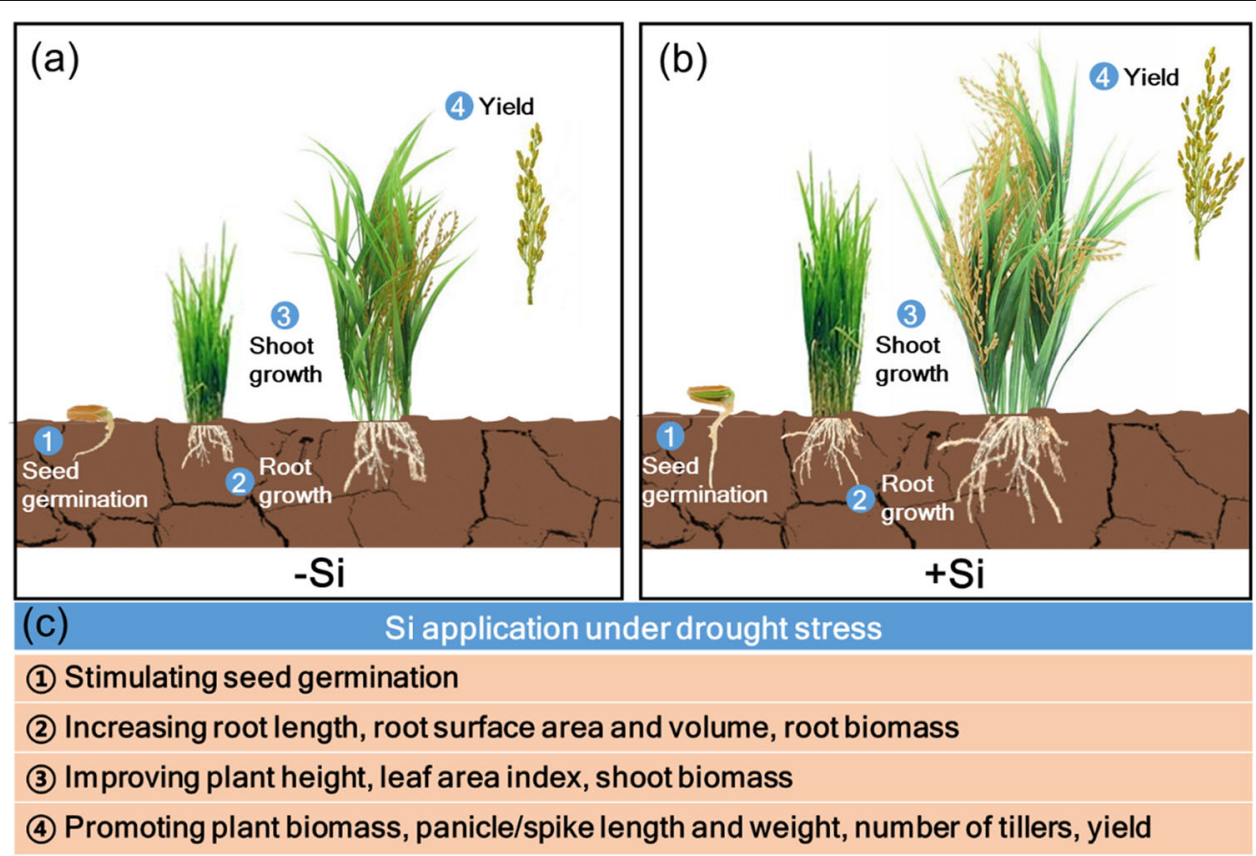

Fig. 1 Beneficial effects of silicon (Si) on the growth and development of plants under drought stress. a Plant growth and yield production in the absence of Si application (-Si). Seed germination, root growth, shoot growth, and crop yields are suppressed by drought without Si application. b Plant growth and yield production in the presence of Si application (+Si). c The beneficial effects of Si under drought stress include stimulating seed germination (1) and increasing both root (2) and shoot growth (3), thus increasing plant biomass and yield (4) under drought stress 
extensively characterized. However, the detailed mechanisms remain unknown and appear to vary according to genotype and environment. In this review, the morphoanatomical, physiological, biochemical, and molecular processes by which $\mathrm{Si}$ alleviates plant drought stress, especially the potential functions of $\mathrm{Si}$ in the accumulator, intermediate, and excluder plants, are summarized. This study provides an overview of the currently available information on Si-mediated root water uptake, leaf water loss, and plant defense responses under drought stress.

\section{Si increases root water uptake under drought stress Improving root/shoot ratios}

Increasing root water uptake by regulating the root surface and anatomy is important for plant stress tolerance $^{51}$. Si is essential for root development and water uptake under drought stress conditions ${ }^{49,52}$. It was suggested that Si application regulates polyamine (PA) and 1aminocyclopropane-1-carboxylic acid (ACC) levels under drought stress conditions to increase root growth and the root/shoot ratio ${ }^{53}$, thus improving root water uptake $\mathrm{e}^{28,32,53-56}$. Such Si-mediated changes in root development also increase root endodermal silicification and suberization ${ }^{54,55}$, therefore enhancing the capability of water retention to overcome the effects of drought stress. Root endodermal development involves three main stages: Casparian band formation, deposition of suberin lamellae, and thickening of cell walls. Si has been shown to promote Casparian band development by crosslinking phenols with the cell wall or by inducing precipitation of phenols ${ }^{56}$. Endodermal silicification associated with cell walls in the roots is arranged in a specific pattern that initiates in endodermal cells adjacent to the phloem, continues to the xylem poles, and is ultimately observed in so-called passage cells ${ }^{57}$. However, in a study of sorghum, endodermal silicification-induced drought resistance was not driven through an improved root water retention capability, and root silicification might help overcome drought stress by decreasing root growth inhibition caused by desiccation ${ }^{58}$.

In contrast, several researchers have reported no effects of $\mathrm{Si}$ on the root/shoot ratio but have reported increases in both the root and shoot dry weight under stress conditions $^{32,52,59}$, and these authors suggested that $\mathrm{Si}$ was effective at improving plant resistance to osmotic stress and that root hydraulic conductance is important for Sipromoted root water uptake ${ }^{31}$. Thus, Si-enhanced water uptake under drought stress conditions could be specific to plant species, genotype, or even environmental conditions. In the following section, the functions of $\mathrm{Si}$ in water uptake and transport are discussed.

\section{Promoting the root osmotic driving force}

Osmotic adjustment and accumulation of compatible cellular solutes are considered plant physiological processes that occur in response to drought stress ${ }^{60,61}$. These adjustments are attributed mainly to turgor maintenance and the protection of specific cellular functions by the accumulation of compatible organic solutes such as amino acids, soluble sugars, and minerals ${ }^{62,63}$, resulting in a favorable osmotic gradient between the plant roots and the growth medium to facilitate water uptake ${ }^{51,64,65}$.

An increasing number of studies have indicated that applying $\mathrm{Si}$ promotes osmolyte accumulation in many plant species, especially $\mathrm{Si}$ accumulators, such as rice, wheat, maize, and sorghum, under drought stress ${ }^{28-30,66}$, thus improving the osmotic driving force for water uptake $^{66}$. In line with this point, Si has been reported to regulate the activities of enzymes involved in carbohydrate metabolism and affect the lignification of cell walls, consequently regulating assimilate synthesis and transport efficiency $^{28-30,38,66-68}$. Other osmotic responses are exhibited by cucumber and wheat plants, which show increased protein content when exposed to salt and drought stress together with $\mathrm{Si}^{29,69}$, and also in chickpea and sunflower plants, in which proline accumulation is induced by $\mathrm{Si}$ under drought stress ${ }^{34,70}$. The accumulation of these osmolytes involves not only osmotic adjustment but also detoxification of ROS, maintenance of membrane integrity, and stabilization of proteins/enzymes, which contribute to drought tolerance. However, another study in tomato (a Si excluder) showed that osmotic events were not affected by $\mathrm{Si}$ under drought ${ }^{32}$, suggesting that the $\mathrm{Si}$ mediated increase in root water uptake was not due to an increase in the osmotic driving force under drought stress but rather was due to an improved root hydraulic conductance. In addition, $\mathrm{Si}$ application alleviated drought stress by decreasing the content of osmolytes in lentil and potato plant species (Si excluders) ${ }^{46,67}$, suggesting that the role of the osmotic driving force in Si-mediated improvement of water uptake differs between the $\mathrm{Si}$ accumulators and excluders. Therefore, the osmotic driving force was not the only important response, and the role of the osmotic driving force in the Si-mediated enhancement of water uptake does not appear to be deployed in all situations.

The abovementioned studies implied that Si application increased plant drought tolerance by regulating osmotic adjustments based on organic solute accumulation. However, since little is known about the mechanisms of $\mathrm{Si}$-mediated osmotic adjustment in plants, the relationship between the Si application and plant-compatible solute metabolism needs future investigation, especially the difference between the $\mathrm{Si}$ accumulators and excluders. 


\section{Increasing root hydraulic conductance}

The root water uptake capacity is largely determined by hydraulic conductance ${ }^{71}$, and $\mathrm{Si}$ application has been reported to improve root hydraulic conductance in $\mathrm{Si}$ accumulators, intermediates, and excluders plants underwater and salt stress ${ }^{31,32,59,66,72-75}$. Root hydraulic conductance can be inhibited by high exogenous hydrogen peroxide $\left(\mathrm{H}_{2} \mathrm{O}_{2}\right)$ levels, which are correlated with membrane electrolyte leakage and ROS levels ${ }^{76} . \mathrm{H}_{2} \mathrm{O}_{2}$ is involved in the formation of suberin lamellae, which form a hydrophobic barrier in the endodermis and exodermis of roots ${ }^{77}$. Under stress conditions, $\mathrm{Si}$ application reduces $\mathrm{H}_{2} \mathrm{O}_{2}$ production and suberin lamella formation and further induces increased water permeability ${ }^{32}$. In tomato plants under drought stress, root plasma membrane integrity was improved in response to $\mathrm{Si}$ application, and negative correlations were found between root hydraulic conductance and the levels of both the ROS and lipid peroxidation products $^{32}$. The Si-mediated alleviation of ROS production under drought stress corresponded with an increase in antioxidant defenses, mainly attributed to the improved activity of catalase (CAT) and superoxide dismutase (SOD), as well as contents of ascorbic acid (AsA) and reduced glutathione $(\mathrm{GSH})^{32}$. Therefore, the enhanced root hydraulic conductance and water uptake in response to $\mathrm{Si}$ could arise from a reduction in membrane oxidative damage $^{32}$. In addition, Si-mediated transcriptional upregulation of root aquaporin genes contributed to increased hydraulic conductance and water uptake under drought stress $^{31}$. It has been reported that oxidative damage causes plasma membrane dysfunction; thus, the overproduction of ROS under drought stress may negatively regulate the activities of plasma membrane aquaporins ${ }^{32}$. The role of aquaporins in root water uptake regulated by $\mathrm{Si}$ under drought stress is discussed in the following sections.

Overall, the modification of root growth and hydraulic conductance in response to $\mathrm{Si}$ application enhances root water uptake under drought stress conditions. A Simediated reduction in membrane oxidative damage via increased antioxidant defense may contribute to enhanced root hydraulic conductance. Further studies are needed to investigate how $\mathrm{Si}$ regulates root development under drought stress conditions. Specifically, the complex interactions between membrane oxidative damage and ROS accumulation in root hydraulic conductance need to be determined.

\section{Regulation of aquaporins (AQPs)}

Aquaporins belong to the major intrinsic protein (MIP) family and regulate the transport of water and small solutes across membranes ${ }^{78-82}$, contributing to root water uptake, especially under drought stress conditions $^{31,71,83,84}$. Water moves within the roots both radially from the root surface into xylem vessels and axially along the xylem ${ }^{85}$, while aquaporins mainly function in radial water movement in both the water uptake and transport. There are three main pathways for water flow in radial movement: the apoplastic, symplastic, and transcellular pathways ${ }^{85}$. The symplastic and transcellular pathways are collectively referred to as the cell-to-cell pathway ${ }^{86}$, which is mainly dependent on aquaporins ${ }^{87}$.

In the presence of $\mathrm{Si}$, there is a dual role played by aquaporins under drought stress. On the one hand, Lsi1, a Si-permeable channel, belongs to a NOD26-like intrinsic protein (NIP) subfamily of aquaporins, which are involved in $\mathrm{Si}$ transport ${ }^{12,88,89}$. As $\mathrm{Si}$ accumulation in plants requires the dual action of both the influx and efflux transporters, the Si transporter Lsi1 has evolved a unique selective amino acid filter, which is one of the required features to regulate the influx of $\mathrm{Si}$ and the indispensable key for plants to absorb $\mathrm{Si}^{12,90}$. On the other hand, $\mathrm{Si}$ induces the expression of aquaporin genes to increase root water uptake ${ }^{73,91}$; for example, in sorghum plants, Si application markedly enhances aquaporin activity via the upregulation of the SbPIP1;6, SbPIP2;2, and SbPIP2;6 genes, consequently increasing root water uptake by enhancing root hydraulic conductance under drought stress $^{31,91,92}$. However, inconsistent results were observed in a $\mathrm{Si}$ excluder (tomato), and the expression of the SIPIP1;3, SIPIP1;5, and SIPIP2;6 genes was not significantly affected after $\mathrm{Si}$ application under drought stress $^{32}$, suggesting that $\mathrm{Si}$ did not improve root water uptake by upregulating aquaporin genes in tomato roots but instead did so by increasing root hydraulic conductance (as mentioned above).

Therefore, the ability of Si to alleviate drought stress is mainly attributed to its direct effect through regulating the activity of aquaporins and gene expression, as well as its indirect effect through increasing root hydraulic conductance (personal communication with Rony Wallach, Hebrew University of Jerusalem). However, the molecular mechanism of Si-mediated alleviation of drought stress is poorly understood, and the genes related to water uptake and osmotic adjustment regulated by $\mathrm{Si}$ need to be determined. Further studies should focus on the underlying interactions between the $\mathrm{Si}$ and processes related to water relations (water uptake, transport, and loss) under stress conditions.

\section{Enhancing mineral nutrient uptake and maintaining nutrient balance}

Mineral nutrient uptake and homeostasis can be disrupted by environmental stimuli, especially drought stresses $^{34,48}$. It has been reported that the uptake of nitrogen $(\mathrm{N})$, phosphate $(\mathrm{P})$, potassium $(\mathrm{K})$, calcium $(\mathrm{Ca})$, magnesium $(\mathrm{Mg})$, iron $(\mathrm{Fe})$, copper $(\mathrm{Cu})$, and manganese $(\mathrm{Mn})$ increases in response to $\mathrm{Si}$ application under 
drought stress $^{30,34,48,93}$, which not only enhances plant growth but also improves plant resistance and/or tolerance. For example, $\mathrm{K}$ and $\mathrm{Ca}$ contents were considerably increased in maize in response to $\mathrm{Si}$ application under drought stress $^{30}$, in which $\mathrm{K}$ benefits plant growth, osmotic adjustment, and drought tolerance ${ }^{94}$, and $\mathrm{Ca}$ is critical for achieving better survival with improved plant growth $^{95}$, maintaining the integrity of plant membranes and regulating ion permeability and selectivity ${ }^{96}$.

The possible mechanisms for Si-induced mineral nutrient uptake include (i) increasing water uptake and transpirational driving forces ${ }^{31,92}$, thus enhancing mineral nutrient movement from soil into roots; (ii) enhancing ion mobilization in roots (e.g., Si alleviates Fe deficiency in cucumber by increasing the apoplastic Fe pool in the roots and enhancing $\mathrm{Fe}$ mobilization in the roots due to $\mathrm{Si}$ mediated biosynthesis of Fe-chelating compounds) ${ }^{97}$; (iii) stimulating membrane $\mathrm{H}^{+}$-ATPase activity driving mineral nutrient uptake (e.g., Si increased $\mathrm{K}^{+}$uptake in barley under osmotic stress by activating $\mathrm{H}^{+}$-ATPase in the membranes) $)^{98}$; (iv) regulating ion transporter genes (e.g., Si modulates the activities and gene expression of enzymes involved in $\mathrm{Fe}$ acquisition in cucumber) ${ }^{97}$, while $\mathrm{Si}$ also regulates genes involved in $\mathrm{Mn}$ and $\mathrm{Cd}$ uptake and translocation in rice ${ }^{99,100}$; and (v) enhancing the translocation of metabolites that contribute to root/shoot ion transport (e.g., Si increases micronutrient transport and distribution by increasing the content of long-distance molecules, such as citrate ${ }^{101}$. In brief, the uptake of essential nutrients in response to $\mathrm{Si}$ application under drought stress maintains the nutrient balance, thereby increasing water uptake and improving plant resistance to environmental stress.

In summary, the beneficial effects of $\mathrm{Si}$ on water uptake may be attributed to the improvement in root growth, driving force, root hydraulic conductance, aquaporin activity, and gene expression, as well as the maintenance of nutrient balance (Fig. 2). The interactions between the $\mathrm{Si}$ and other essential nutrients under drought stress are worthy of further study to explore the role of $\mathrm{Si}$ in root water uptake.

\section{Si regulates leaf water loss under drought stress}

Numerous researchers have shown that $\mathrm{Si}$ application regulates gas exchange, which in turn contributes to drought tolerance, in species such as maize ${ }^{93,102}$, soybean ${ }^{103}$, cucumber ${ }^{104}$, and alfalfa ${ }^{105}$; this ultimately resulted in increased water-use efficiency (WUE) and the alleviation of drought stress ${ }^{93}$. In previous studies, $\mathrm{Si}$ induced reduction in transpiration was considered to be the result of physical blockade of cuticular transpiration via cuticle layer thickening from silica deposits ${ }^{106-108}$, which contributes to the maintenance of leaf water potential underwater-deficient conditions ${ }^{54}$. For example,

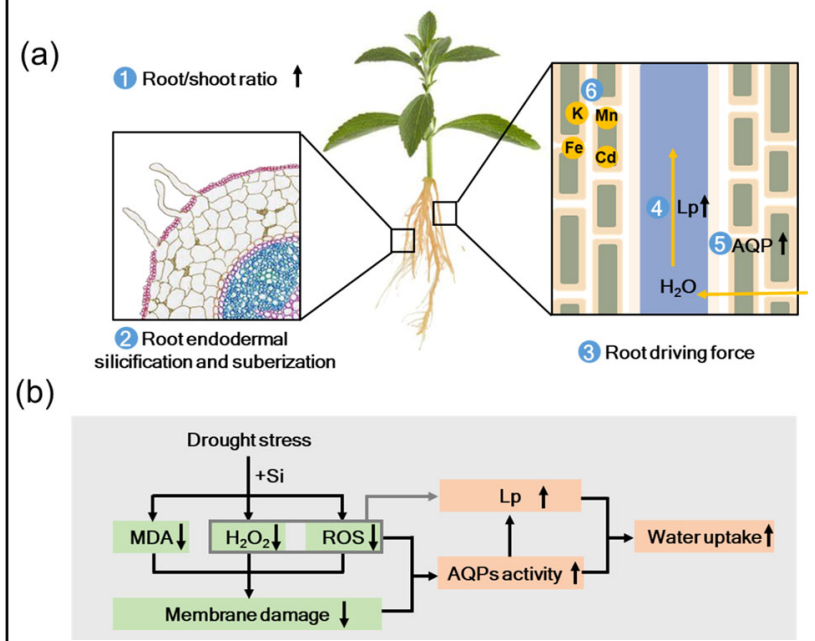

Fig. 2 Water uptake increases in response to Si application under drought stress conditions. a Silicon (Si) application acts via the following mechanisms: (1) increasing the root/shoot ratio; (2) inducing root endodermal silicification and suberization; (3) enhancing the root driving force; (4) improving root hydraulic conductance (LP); (5) increasing aquaporin (AQP) activity; and (6) maintaining nutrient balance. $\mathbf{b}$ Root hydraulic conductance and aquaporins are regulated by Si under drought stress. Si application improves root Lp by inhibiting reactive oxygen species (ROS) and hydrogen peroxide $\left(\mathrm{H}_{2} \mathrm{O}_{2}\right)$ production and increases AQP activity by reducing ROS production and membrane damage, thus improving water uptake

wheat leaves are thicker after Si application under drought, thus reducing transpirational water loss ${ }^{109,110}$. However, in maize plants, it was suggested that the lower transpiration of Si-supplied plants was primarily due to stomatal pores rather than the cuticular layer ${ }^{93,102}$, mainly attributed to the loss of guard cell turgor and changes in the physical and mechanical properties of the cell walls ${ }^{111-113}$.

In contrast to the abovementioned observations, some reports have suggested that $\mathrm{Si}$ application increased the leaf transpiration rate in rice, tomato, pepper, mangrove, and sorghum under drought stress ${ }^{31,32,48,114,115}$. This increased transpiration was attributed to an improvement in leaf water status via increased water uptake, enhanced leaf xylem sap flow, and increased leaf water potential resulting from a larger leaf area ${ }^{110}$. Such results were also consistent with those of Zhang et al. ${ }^{116}$, who suggested that Si-improved plant growth may be attributed to increased gas exchange parameters, e.g., transpiration and stomatal conductance. However, it has also been reported that $\mathrm{Si}$ has no effect on the transpiration rates of cucumber and rose plants under drought stress conditions ${ }^{117,118}$, implying that Si-regulated transpiration is dynamic and depends on root water status, environmental conditions, plant species, and genotype.

The role of $\mathrm{Si}$ in alleviating drought stress by regulating transpiration is summarized in Fig. 3. When root water 


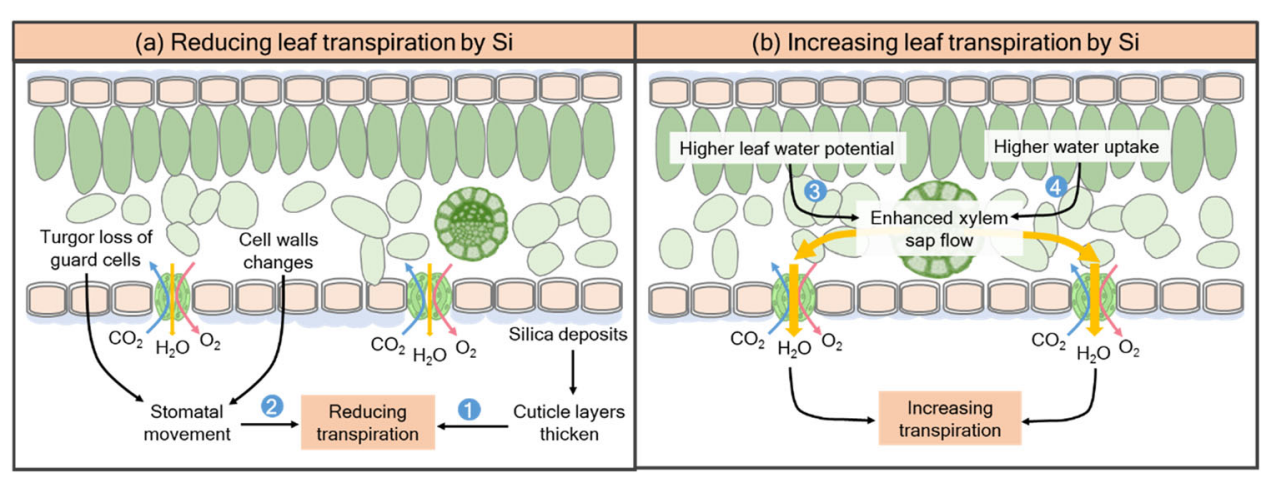

Fig. 3 Si influences leaf transpiration under drought stress. a Leaf transpiration can be reduced by Si application under drought stress via (1) physical blockade of cuticular transpiration via cuticle layer thickening caused by silica deposits and via (2) regulation of stomatal movement by turgor loss of guard cells and by changes in the physical and mechanical properties of cell walls. $\mathbf{b}$ In contrast, Si application increased the leaf water potential (3) and water uptake (4), thus enhancing leaf xylem sap flow and transpiration under drought stress conditions. In addition, Si has also been reported to have no effect on leaf transpiration in some cases

uptake was limited, this model suggested that the $\mathrm{Si}$ supply decreased leaf transpiration to reduce water loss by physically blocking cuticular transpiration or stomatal movement. In contrast, Si increased leaf xylem sap flow and transpiration rates under drought stress, corresponding to increased photosynthesis rates. The differential impact of Si on transpiration rates may be related to the degree of stress. Under mild stress conditions, Si could increase root water uptake, corresponding to increased transpiration rates, and consequently increase plant growth under drought stress. When root water uptake is limited under heavy stress, plant leaves close their stomata to reduce water loss, which occurs most likely through a systemic signaling event(s). More broadly, leaf transpiration exerts feedback effects on root water transport models $^{71}$. With high leaf transpiration rates, the transpiration force driving water across the roots mainly depends on the hydrostatic pressure difference between the root medium and xylem, which allows both the apoplastic and cell-to-cell pathways to be used. When transpiration is reduced, only a cell-to-cell process is available, which has high hydraulic resistance ${ }^{71}$. Nonetheless, detailed studies are still needed to understand the mechanisms of $\mathrm{Si}$ in whole-plant water relations and to consider the complex relationship between Si supply and transpiration in plants under drought.

\section{Si invokes plant defense responses under drought stress}

\section{Modification of signaling pathways}

To alleviate environmental stress, plants have developed a complex signal transduction network. Si application has been reported to increase plant tolerance by regulating endogenous plant phytohormone balance and associated signaling events, including those involving abscisic acid (ABA), JA, salicylic acid (SA), and $\mathrm{ET}^{22,53,119-121}$.
For example, Si addition enhanced the drought tolerance of sorghum, at least in part, by regulating the synthesis of PAs, as well as ACC, the precursor of $\mathrm{ET}^{53}$. Furthermore, Si decreased JA contents in soybean under drought ${ }^{122}$, which suggested $\mathrm{Si}$ inhibited an early signaling event required for JA production. ABA, a stress-responsive hormone, plays an essential role in stomatal closure when plants are exposed to various environmental stresses ${ }^{123}$. In barley plants, $\mathrm{Si}$ application did not affect ABA levels in the leaves under normal conditions but decreased $A B A$ homeostasis via transcriptional regulation of ABA biosynthesis and degradation pathways, thus improving stress tolerance ${ }^{124}$.

Several studies have proposed that $\mathrm{Si}$ mediates the modulation of multiple genes involved in stressresponsive pathways via the JA, $\mathrm{ABA}$, and phenylpropanoid pathways ${ }^{125-128}$. In rice, Si regulates the transcription factors OsNAC5 and OsDREB2A, which trigger the expression of stress-responsive genes that impart tolerance to osmotic stress via ABA-dependent and ABAindependent pathways, respectively ${ }^{129,130}$. The Sidependent upregulation of transcription factors could interact with cis-elements located in the promoter regions of genes involved in the stress response and trigger tolerance to abiotic and biotic stresses ${ }^{126}$. Given the current knowledge of these phytohormone signaling pathways, the means through which $\mathrm{Si}$ impacts particular components and affects crosstalk between signals under stress conditions must be urgently addressed.

\section{Activation of the antioxidant system}

The balance between ROS and antioxidants is disrupted by environmental stresses, resulting in oxidative damage to membrane lipids ${ }^{131,132}$. The antioxidative processes that reduce ROS in plant cells include both the enzymes [e.g., SOD, CAT, peroxidase (POD) and ascorbate 
peroxidase (APX)] and nonenzymatic compounds [e.g., AsA, GSH, tocopherols, and carotenoids] $]^{29,41}$. ROS accumulation under drought stress is inversely correlated with the activities of plasma membrane aquaporins ${ }^{76}$. Indeed, aquaporin phosphorylation status and intracellular trafficking are regulated by ROS-dependent signaling mechanisms $^{133}$. Therefore, the regulation of water movement by $\mathrm{Si}$ is directly affected by the ROS-mediated process.

$\mathrm{Si}$ application enhances the resistance and tolerance of plants under drought stress by increasing plant defense responses, such as those of the antioxidant system, thereby reducing drought-induced oxidative stress ${ }^{70,111}$. In particular, $\mathrm{Si}$ increased the activities of SOD, CAT, and APX in wheat ${ }^{29}$, tomato $^{41}$, chickpea ${ }^{70}$, rapeseed, and sunflower ${ }^{34}$, which in turn induced $\mathrm{H}_{2} \mathrm{O}_{2}$ production and lipid peroxidation underwater-deficient conditions. However, Si application decreased CAT, POD, and SOD activities and electrolyte leakage in soybean plants under drought stress $^{35}$, indicating that oxidative damage induced by drought was alleviated by $\mathrm{Si}$. Nevertheless, in drought-stressed wheat leaves, $\mathrm{Si}$ addition increased SOD activity while decreasing $\mathrm{H}_{2} \mathrm{O}_{2}$ and malondialdehyde (MDA) levels and electrolyte leakage $e^{29,134,135}$, suggesting that the different responses of enzyme activities to drought stress might be attributed to differences in plant species, growth stage, and stress degree. An essential role in alleviating oxidative damage in plants is also played by nonenzymatic antioxidants, and $\mathrm{Si}$ application increased GSH and AsA contents in drought-stressed wheat ${ }^{29,134}$. Moreover, activities of nonenzymatic antioxidants (e.g., AsA) in chickpea were induced by Si under drought stress conditions ${ }^{70}$, indicating that oxidative damage induced by drought was mitigated by $\mathrm{Si}$ by enhancing the activity of antioxidative systems. AsA reacts nonenzymatically with superoxide, $\mathrm{H}_{2} \mathrm{O}_{2}$, and singlet oxygen and reacts indirectly by regenerating tocopherols or synthesizing zeaxanthin in the xanthophyll cycle, which influences several enzyme activities and reduces the damage caused by the oxidative process through synergistic functions with those of other antioxidants ${ }^{136}$. The mechanisms by which $\mathrm{Si}$ activates antioxidant systems under drought stress are largely unknown; but it has been suggested that $\mathrm{Si}$ is involved in regulating the expression of genes related to the production and activation of antioxidant enzymes, such as TaSOD, TaCAT, and TaAPX ${ }^{137}$ under stress conditions. Moreover, exogenous application of Si alleviates drought stress through transcriptional regulation of enzymes involved in the ascorbate-glutathione (ASC-GSH) cycle (e.g., GS, GR, MDHAR, and DHAR) and in flavonoid secondary metabolism (e.g., PAL, CHS, F3H, DFR, and ANS) ${ }^{137}$.

To date, it has been found that $\mathrm{Si}$ can alleviate oxidative damage under drought stress by modulating plant antioxidant defense systems based on enzymatic or nonenzymatic constituents, which contributes to increased plant growth and whole-plant water balance. However, the importance of Si-mediated antioxidant defense largely depends upon plant species, cultivar, and growth stage, as well as the degree of stress and growth conditions. The underlying mechanisms by which $\mathrm{Si}$ alleviates oxidative damage under drought still need to be investigated, especially the role of $\mathrm{Si}$ in regulating the balance between ROS accumulation and antioxidant production.

\section{Conclusion and implications}

Drought stress is one of the major environmental factors that limits plant growth and crop productivity; this review summarizes the effects of $\mathrm{Si}$ on plant resistance and tolerance to drought stress (Table 1). Si application

Table 1 Morphoanatomical, physiological, biochemical, and molecular processes involved in Si alleviation of drought stress in plants

\begin{tabular}{|c|c|c|c|c|}
\hline Process & Resistance mechanism & Plant species & Response & Reference(s) \\
\hline \multirow[t]{10}{*}{ Morphoanatomical } & \multirow[t]{5}{*}{ Stimulating seed germination } & Tomato (Solanum lycopersicum L.) & (+) 22 39\% & [41] \\
\hline & & Wheat (Triticum aestivum L.) & (+) 13 37\% & [44] \\
\hline & & Maize (Zea mays L.) & (NS) & {$[45]$} \\
\hline & & Lentil (Lens culinaris Medik.) & $(+) 16 \sim 55 \%$ & {$[46]$} \\
\hline & & Rice (Oryza sativa) & $(+) 8 \sim 10 \%$ & [47] \\
\hline & \multirow[t]{5}{*}{ Improving root traits } & Upland rice (Oryza sativa) & Root dry weight (+) 23\% & [28] \\
\hline & & Sunflower (Helianthus annuus L.) & Root dry weight (NS) & [34] \\
\hline & & Soybean (Glycine max L.) & Root dry weight (+) 34\% & [35] \\
\hline & & $\begin{array}{l}\text { Canola (Brassica napus L. } \\
\text { cv. Okapi) }\end{array}$ & Root dry weight (+) 47\% & [38] \\
\hline & & Rice (Oryza sativa) & $\begin{array}{l}\text { Total root length }(+) \quad 40 \sim 65 \% \\
\text { Root surface area }(+) \text { 19 38\% } \\
\text { Root volume }(+) \text { 22 40\% }\end{array}$ & {$[48]$} \\
\hline
\end{tabular}


Table 1 continued

\begin{tabular}{|c|c|c|c|c|}
\hline Process & Resistance mechanism & Plant species & Response & Reference(s) \\
\hline & \multirow{11}{*}{ Increasing shoot growth } & Sorghum (Sorghum bicolor L.) & $\begin{array}{l}\text { Root dry weight (+) } 74 \%{ }^{[53]} \\
(+) 93 \%{ }^{[59]} \\
(+) 110 \% \\
\text { Root diameter (+) } 16 \%{ }^{[66]} \\
\text { Root dry weight (NS) }\end{array}$ & {$[53,59,66]$} \\
\hline & & Cucumber (Cucumis sativus L.) & $\begin{array}{l}\text { Root surface area }(+) 39 \% \\
\text { Root mean diameter }(+) 18 \%\end{array}$ & [73] \\
\hline & & Wheat (Triticum aestivum L.) & Root dry weight (NS) & [109] \\
\hline & & Upland rice (Oryza sativa) & Shoot dry weight $(+) 18 \%$ & [28] \\
\hline & & Tomato (Solanum Iycopersicum L.) & Shoot dry weight $(+) 42 \%$ & [32] \\
\hline & & Soybean (Glycine max L.) & Shoot dry weight $(+) 26 \%$ & [35] \\
\hline & & $\begin{array}{l}\text { Canola (Brassica napus L. } \\
\text { cv. Okapi) }\end{array}$ & Shoot dry weight $(+) 76 \%$ & [38] \\
\hline & & Rice (Oryza sativa) & $\begin{array}{l}\text { Shoot weight }(+) 97-103 \%{ }^{[48]} \\
\text { Plant height }(+) 4 \sim 9 \%\end{array}$ & {$[48,50]$} \\
\hline & & Sorghum (Sorghum bicolor L.) & $\begin{array}{l}\text { Shoot dry weight (+) } 41 \%{ }^{[53]} \\
(+) 71 \%{ }^{[59]} \\
(+) 78 \%\end{array}$ & {$[53,59,66]$} \\
\hline & & Cucumber (Cucumis sativus L.) & Shoot dry weight (+) 32\% & [68] \\
\hline & & Wheat (Triticum aestivum L.) & Plant height (NS) & [109] \\
\hline & \multirow[t]{4}{*}{ Increasing the root/shoot ratio } & Upland rice (Oryza sativa) & $(+) 9 \%$ & {$[28]$} \\
\hline & & Tomato (Solanum lycopersicum L.) & (NS) & [32] \\
\hline & & Soybean (Glycine max L.) & $(+) 7 \%$ & [35] \\
\hline & & Sorghum (Sorghum bicolor L.) & $\begin{array}{l}\text { (+) } 4 \%[53] \\
\text { (NS) }{ }^{[59,66]}\end{array}$ & {$[53,59,66]$} \\
\hline \multirow[t]{23}{*}{ Physiological } & \multirow[t]{4}{*}{ Enhancing osmotic adjustment } & Upland rice (Oryza sativa) & $\begin{array}{l}\text { Root osmotic adjustment }(+) \text { 134\% } \\
\text { Leaf osmotic adjustment }(+) 63 \%\end{array}$ & [28] \\
\hline & & Sorghum (Sorghum bicolor L.) & $\begin{array}{l}\text { Root xylem osmotic adjustment (NS) }{ }^{[31]} \\
\text { Leaf osmotic adjustment }(+) 15 \% \\
\text { Root osmotic adjustment }(+) 7 \%{ }^{[53]}\end{array}$ & {$[31,53]$} \\
\hline & & Tomato (Solanum lycopersicum L.) & Root osmotic adjustment (+) 15\% & [32] \\
\hline & & Cucumber (Cucumis sativus L.) & Root xylem osmotic adjustment (+) 39\% & [73] \\
\hline & \multirow{6}{*}{$\begin{array}{l}\text { Enhancing water-use efficiency } \\
\text { (WUE) }\end{array}$} & Upland rice (Oryza sativa) & (+) $176 \%$ & [28] \\
\hline & & $\begin{array}{l}\text { Canola (Brassica napus L. } \\
\text { cv. Okapi) }\end{array}$ & $(+) 20 \%$ & [38] \\
\hline & & Rice (Oryza sativa) & $(+) 119 \%$ & [48] \\
\hline & & Maize (Zea mays L.) & $(+) 30 \%$ & [93] \\
\hline & & Alfalfa (Medicago sativa L.) & (+) 20 36\% & [105] \\
\hline & & Sorghum (Sorghum bicolor L.) & (NS) & [110] \\
\hline & \multirow[t]{6}{*}{ Increasing the photosynthetic rate } & Upland rice (Oryza sativa) & $(+) 260 \%$ & [28] \\
\hline & & Wheat (Triticum aestivum L.) & $(+) 59 \%$ & [29] \\
\hline & & Tomato (Solanum lycopersicum L.) & $(+) 143 \%$ & [32] \\
\hline & & $\begin{array}{l}\text { Canola (Brassica napus L. } \\
\text { cv. Okapi) }\end{array}$ & $(+) 61 \%$ & [38] \\
\hline & & Rice (Oryza sativa) & $(+) 37 \%$ & [48] \\
\hline & & Sorghum (Sorghum bicolor L.) & $\begin{array}{l}\text { (+) } 17 \%{ }^{[91]} \\
(+) 118 \%\end{array}$ & {$[91,110]$} \\
\hline & \multirow[t]{4}{*}{ Increasing water potential } & Upland rice (Oryza sativa) & (+) $17 \sim 27 \%{ }^{[28]}$ & [28] \\
\hline & & Sorghum (Sorghum bicolor L.) & $\begin{array}{l}(+) 13 \%{ }^{[31]} \\
(+) 16 \%\end{array}$ & {$[31,110]$} \\
\hline & & Rice (Oryza sativa) & $(+) 15 \%$ & [48] \\
\hline & & Wheat (Triticum aestivum L.) & $\begin{array}{l}\text { (+) } 15 \%{ }^{[29]} \\
\text { (+) } 40 \%\end{array}$ & {$[29,109]$} \\
\hline & \multirow[t]{3}{*}{ Increasing hydraulic conductance } & Tomato (Solanum lycopersicum L.) & Root hydraulic conductance (+) 375\% & [32] \\
\hline & & Cucumber (Cucumis sativus L.) & Root hydraulic conductance (+) 160\% & [73] \\
\hline & & Sorghum (Sorghum bicolor L.) & $\begin{array}{l}\text { Whole-plant hydraulic conductance }(+) \\
52 \%{ }^{[31]} \\
\text { Root hydraulic conductance }(+) 19 \%{ }^{[91]}\end{array}$ & {$[31,91]$} \\
\hline
\end{tabular}


Table 1 continued

\begin{tabular}{|c|c|c|c|c|}
\hline Process & Resistance mechanism & Plant species & Response & Reference(s) \\
\hline & Modifying transpiration & $\begin{array}{l}\text { Upland rice (Oryza sativa) } \\
\text { Tomato (Solanum lycopersicum L.) }\end{array}$ & $\begin{array}{l}(+) 32 \% \\
(+) 55 \%\end{array}$ & $\begin{array}{l}{[28]} \\
{[32]}\end{array}$ \\
\hline & & Soybean (Glycine max L.) & (+) $29 \%$ & [35] \\
\hline & & Rice (Oryza sativa) & $(+) 19 \%$ & [48] \\
\hline & & Sorghum (Sorghum bicolor L.) & $\begin{array}{l}\text { (+) } 24 \%{ }^{[31]} \\
(+) 25 \%\end{array}$ & {$[31,91]$} \\
\hline & & Alfalfa (Medicago sativa L.) & (+) $25-52 \%$ & {$[105]$} \\
\hline & & Maize (Zea mays L.) & $\begin{array}{l}(-) 30 \%{ }^{[93]} \\
(-) 33 \sim 35 \%{ }^{[102]}\end{array}$ & {$[93,102]$} \\
\hline \multirow[t]{17}{*}{ Biochemical } & Activating antioxidant systems & Wheat (Triticum aestivum L.) & $\begin{array}{l}\text { Root SOD (+) 22\% } \\
\text { CAT }(+) 9 \%\end{array}$ & [29] \\
\hline & & Tomato (Solanum lycopersicum L.) & $\begin{array}{l}\text { Root SOD }(+) 74 \% \\
\text { CAT }(+) 65 \%\end{array}$ & [32] \\
\hline & & Sunflower (Helianthus annuus L.) & Shoots CAT (+) 20\% & [34] \\
\hline & & $\begin{array}{l}\text { Canola (Brassica napus L. } \\
\text { cv. Okapi) }\end{array}$ & $\begin{array}{l}\text { Leaf SOD }(+) 116 \% \\
\text { POD }(+) 175 \% \\
\text { Root SOD }(+) 20 \% \\
\text { POD }(+) 27 \%\end{array}$ & [38] \\
\hline & & Cucumber (Cucumis sativus L.) & $\begin{array}{l}\text { Leaf GPX (+) } 54 \% \\
\text { SOD (+) } 21 \%\end{array}$ & [69] \\
\hline & & Chickpea (Cicer arietinum L.) & $\begin{array}{l}\text { Shoot SOD (NS) } \\
\text { CAT }(+) 106 \%\end{array}$ & [70] \\
\hline & & Sorghum (Sorghum bicolor L.) & $\begin{array}{l}\text { Root SOD }(+) 20 \% \\
\text { CAT }(+) 27 \% \\
\text { APX (NS) }\end{array}$ & [91] \\
\hline & $\begin{array}{l}\text { Activating nonenzymatic } \\
\text { antioxidants }\end{array}$ & Tomato (Solanum Iycopersicum L.) & $\begin{array}{l}\text { Root AsA (+) } 62 \% \\
\text { GSH }(+) 44 \%\end{array}$ & [32] \\
\hline & & Sunflower (Helianthus annuus L.) & Shoot $(+) 19 \%$ & [34] \\
\hline & & Chickpea (Cicer arietinum L.) & Shoot $(+) 18 \%$ & [70] \\
\hline & Alleviating oxidative stress & Wheat (Triticum aestivum L.) & Root $\mathrm{H}_{2} \mathrm{O}_{2}(-) 30 \%$ & [29] \\
\hline & & Tomato (Solanum lycopersicum L.) & $\begin{array}{l}\text { Root } \mathrm{H}_{2} \mathrm{O}_{2}(-) 36 \sim 39 \% \\
\mathrm{MDA}(-) 16 \sim 45 \% \\
\mathrm{O}_{2}^{--}-(-) 15 \% \sim 23 \%\end{array}$ & [32] \\
\hline & & Sunflower (Helianthus annuus L.) & $\begin{array}{l}\text { Shoot } \mathrm{H}_{2} \mathrm{O}_{2}(-) 25 \% \\
\text { MDA (-) } 11 \%\end{array}$ & [34] \\
\hline & & $\begin{array}{l}\text { Canola (Brassica napus L. } \\
\text { cv. Okapi) }\end{array}$ & $\begin{array}{l}\text { Leaf } \mathrm{H}_{2} \mathrm{O}_{2}(-) 9 \% \\
\mathrm{MDA}(-) 39 \% \\
\text { Root } \mathrm{H}_{2} \mathrm{O}_{2}(-) 47 \% \\
\text { MDA }(-) 57 \%\end{array}$ & [38] \\
\hline & & Cucumber (Cucumis sativus L.) & $\begin{array}{l}\text { Leaf } \mathrm{H}_{2} \mathrm{O}_{2}(-) 18 \%{ }^{[69]} \sim 19 \%{ }^{[68]} \\
\mathrm{MDA}(-) 24{ }^{[69]} \sim 52 \%{ }^{[68]} \\
\text { Root } \mathrm{H}_{2} \mathrm{O}_{2}(-) 23 \% \\
\mathrm{MDA}(-) 22 \%\end{array}$ & {$[68,69]$} \\
\hline & & Chickpea (Cicer arietinum L.) & $\begin{array}{l}\text { Shoot } \mathrm{H}_{2} \mathrm{O}_{2}(-) 42 \% \\
\text { MDA (-) } 11 \% \\
\text { LOX (-) } 8 \%\end{array}$ & [70] \\
\hline & & Sorghum (Sorghum bicolor L.) & Root $\mathrm{H}_{2} \mathrm{O}_{2}(-) 50 \%$ & [91] \\
\hline \multirow[t]{7}{*}{ Molecular } & Regulating aquaporins & Tomato (Solanum lycopersicum L.) & SbPIP relative expression (+) 60 165\% & [32] \\
\hline & & Cucumber (Cucumis sativus L.) & CsPIP relative expression (+) 90 160\% & [73] \\
\hline & & Sorghum (Sorghum bicolor L.) & $\begin{array}{l}\text { SbPIP relative expression }(+) \text { 18 } 237 \%{ }^{[31]} \\
\text { SbPIP expression upregulated }{ }^{[91]}\end{array}$ & {$[31,91]$} \\
\hline & Modifying signaling pathways & Sorghum (Sorghum bicolor L.) & $\begin{array}{l}\text { Leaf PAs }(+) 80 \% \\
\text { Root PAs }(+) 67 \%\end{array}$ & [53] \\
\hline & & Soybean (Glycine max L.) & $\begin{array}{l}\text { Gibberellins (GAs) (+) 53\% } \\
\text { JA (-) } 38 \% \\
\text { SA (-) } 29 \%\end{array}$ & [122] \\
\hline & & Barley (Hordeum vulgare cv.) & $\begin{array}{l}\text { ABA (+) } 97 \% \\
\text { Phaseic acid }(+) 74 \% \\
\text { Dehydro-phaseic acid (DPA) (+) 57\% } \\
\text { Cytokinin Ip (+) } 76 \%\end{array}$ & [124] \\
\hline & & Wheat (Triticum aestivum L.) & $\begin{array}{l}\text { TaSOD relative expression (+) } 26 \% \\
\text { TaAPX relative expression (+) } 112 \% \\
\text { TaCAT relative expression (+) } 200 \%\end{array}$ & [137] \\
\hline
\end{tabular}

Positive $(+)$, negative $(-)$, and no effect (NS no significant difference) of silicon (Si) on plant drought resistance. The response data were calculated as follows: (Si supply - without Si supply)/without Si supply $\times 100 \%$ (under drought stress) 


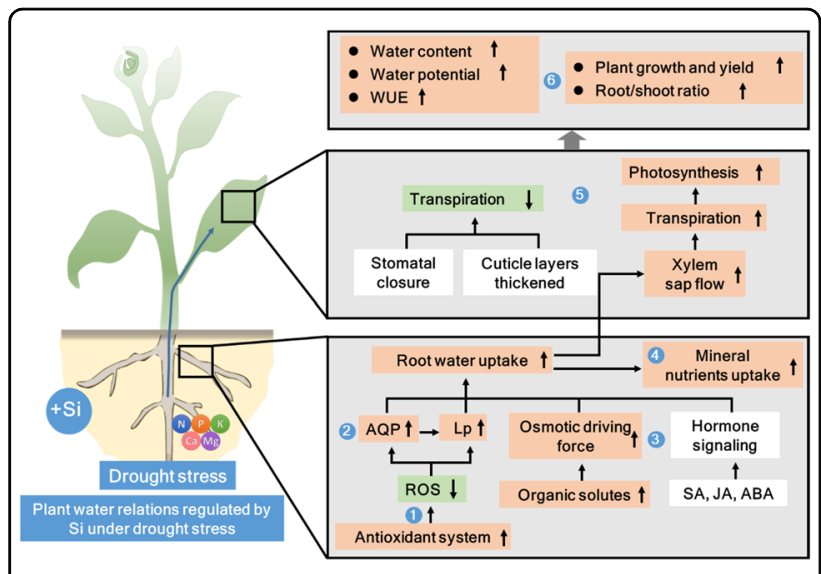

Fig. 4 Key mechanisms involved in Si-triggered drought stress in plants. Plant water relations regulated by Si under drought stress conditions include (1) activation of antioxidant systems, (2) stimulation of gene expression and defense responses, (3) adjustment of osmotic processes and maintenance of homeostasis, (4) increases in nutrient uptake and maintenance of mineral balance, (5) regulation of photosynthesis and gas exchange, and (6) improvements in plant growth and water uptake tolerance and/or resistance under field conditions still need to be extensively investigated.

\section{Acknowledgements}

This work was financially supported by the National Key R\&D Program (2016YFD0200900), the Fundamental Research Funds for the Central Universities (KYGD202007), the National Natural Science Foundation of China (32072673), and the Young Elite Scientists Sponsorship Program by CAST (2018QNRC001).

\section{Author details}

${ }^{1}$ Jiangsu Provincial Key Lab of Solid Organic Waste Utilization, Jiangsu Collaborative Innovation Center of Solid Organic Wastes, The Key Laboratory of Plant Immunity, Nanjing Agricultural University, Nanjing 210095 Jiangsu, China. ${ }^{2}$ Institute of Biological, Environmental and Rural Sciences, Aberystwyth University, Aberystwyth SY23 3DA, UK. ${ }^{3}$ Key Laboratory of Tea Plant Biology and Resources Utilization (Ministry of Agriculture), Tea Research Institute, Chinese Academy of Agricultural Sciences, Hangzhou 310008 Zhejiang, China

\section{Competing interests}

The authors declare no competing interests.

Received: 26 January 2021 Revised: 4 August 2021 Accepted: 19 August 2021

Published online: 01 December 2021 alleviates plant drought stress by (i) enhancing root water uptake, mainly through improving root growth, osmotic driving forces, hydraulic conductance, and mineral nutrient uptake, as well as by regulating aquaporin (AQP) activity and gene expression, (ii) regulating leaf transpirational water loss depending on root water status, and (iii) inducing plant defense responses through modification of signaling pathways and activation of antioxidant systems (Fig. 4). This makes $\mathrm{Si}$ application an attractive approach to improving plant water status and maintaining plant water balance under drought stress conditions. Understanding the interactions between $\mathrm{Si}$ application and plant responses will contribute to more efficient fertilization practices or enhanced stress tolerance of crop plants.

Based on the current knowledge, the distribution of $\mathrm{Si}$ and its functions under stress conditions need further investigation, especially the differences among $\mathrm{Si}$ accumulators, intermediates, and excluders and the strategies for alleviating drought stress. In addition, published works are inconsistent, which may reflect the absence of a "onesize-fits-all" model for $\mathrm{Si}$ effects, with differences in mechanisms depending on species, genotypes, and the environment. This needs to be recognized before $\mathrm{Si}$ can be successfully applied to agriculture. Therefore, a systematic assessment of $\mathrm{Si}$ effects is needed, in which the effects could be linked to, for example, specific quantitative trait loci (QTLs) and/or transcriptomic assessments. In addition, to overcome global environmental changes and improve crop production, the application method of $\mathrm{Si}$ (e.g., soil-based or foliar) and its effect on plant

\section{References}

1. Epstein, E. Silicon. Annu. Rev. Plant Physiol. 50, 641-664 (1999).

2. Epstein, E. The anomaly of silicon in plant biology. P. Natl Acad. Sci. USA 91, 11-17 (1994).

3. Savant, N. K., Snyder, G. H. \& Datnoff, L. E. Silicon management and sustainable rice production. Adv. Agron. 58, 151-199 (1997).

4. Ma, J. F. \& Yamaji, N. Silicon uptake and accumulation in higher plants. Trends Plant Sci. 11, 392-397 (2006).

5. Coskun, D., Britto, D. T., Huynh, W. Q. \& Kronzucker, H. J. The role of silicon in higher plants under salinity and drought stress. Front. Plant Sci. 7, 1072 (2016).

6. Cooke, J., DeGabriel, J. L. \& Hartley, S. E. The functional ecology of plant silicon: geoscience to genes. Funct. Ecol. 30, 1270-1276 (2016).

7. Coskun, D. et al. The controversies of silicon's role in plant biology. N. Phytol. 221, 67-85 (2019).

8. Luyckx, M., Hausman, J., Lutts, S. \& Guerriero, G. Silicon and plants: current knowledge and technological perspectives. Front. Plant Sci. 8, 411 (2017).

9. Liang, Y. et al. Importance of plant species and external silicon concentration to active silicon uptake and transport. N. Phytol. 172, 63-72 (2006).

10. Takahashi, E., Ma, J. F. \& Miyake, Y. The possibility of silicon as an essential element for higher plants. J. Agric. Food Chem. 2, 99-102 (1990).

11. Richmond, K. E. \& Sussman, M. Got silicon? The non-essential beneficial plant nutrient. Curr. Opi. Plant Biol. 6, 268-272 (2003)

12. Ma, J. F. \& Yamaji, N. A cooperative system of silicon transport in plants. Trends Plant Sci. 20, 435-442 (2015).

13. Yamaji, N., Mitatni, N. \& Ma, J. F. A transporter regulating silicon distribution in rice shoots. Plant Cell 20, 1381-1389 (2008).

14. de Oliveira, R. L. L., de Mello Prado, R., Felisberto, G. \& Cruz, F. J. R. Different sources of silicon by foliar spraying on the growth and gas exchange in sorghum. J. Soil Sci. Plant Nut. 19, 948-953 (2019).

15. de Souza Junior, J. P. et al. Effect of different foliar silicon sources on cotton plants. J. Soil Sci. Plant Nut. 21, 95-103 (2021).

16. Flores, R. A. et al. Nutrition and production of Helianthus annuus in a function of application of leaf silicon. J. Plant Nutr. 42, 137-144 (2019).

17. Hussain, S. et al. Foliar application of silicon improves stem strength under low light stress by regulating lignin biosynthesis genes in soybean (Glycine max (L.) Merr.). J. Hazard. Mater. 401, 123256 (2021).

18. Puppe, D. \& Sommer, M. Experiments, uptake mechanisms, and functioning of silicon foliar fertilization-a review focusing on maize, rice, and wheat. Adv. Agron. 152, 1-49 (2018). 
19. Morato de Moraes, D. H. et al. Combined effects of induced water deficit and foliar application of silicon on the gas exchange of tomatoes for processing. Agron. 10, 1715 (2020).

20. Pilon, C., Soratto, R. P., Broetto, F. \& Fernandes, A. M. Foliar or soil applications of silicon alleviate water-deficit stress of potato plants. Agron. J. 106, 2325-2334 (2014).

21. Cooke, J., Leishman, M. R. \& Hartley, S. Consistent alleviation of abiotic stress with silicon addition: a meta-analysis. Funct. Ecol. 30, 1340-1357 (2016).

22. Wang, M. et al. Role of Silicon on Plant-Pathogen Interactions. Front. Plant Sci. 8, 701 (2017).

23. Meharg, C. \& Meharg, A. A. Silicon, the silver bullet for mitigating biotic and abiotic stress, and improving grain quality, in rice? Environ. Exp. Bot. 120, 8-17 (2015).

24. Debona, D., Rodrigues, F. A. \& Datnoff, L. E. Silicon's role in abiotic and biotic plant stresses. Annu. Rev. Phytopathol. 55, 85-107 (2017).

25. Thorne, S. J., Hartley, S. E. \& Maathuis, F. J. M. Is silicon a panacea for alleviating drought and salt stress in crops? Front. Plant Sci. 11, 1221 (2020).

26. Vandegeer, R. K. et al. Leaf silicification provides herbivore defence regardless of the extensive impacts of water stress. Funct. Ecol. 35, 1200-1211 (2021).

27. Schwalm, C. R. et al. Global patterns of drought recovery. Nature 548, 202 (2017).

28. Ming, D. F., Pei, Z. F., Naeem, M. S., Gong, H. J. \& Zhou, W. J. Silicon alleviates PEG-induced water-deficit stress in upland rice seedlings by enhancing osmotic adjustment. J. Agron. Crop Sci. 198, 14-26 (2012).

29. Gong, H., Zhu, X., Chen, K., Wang, S. \& Zhang, C. Silicon alleviates oxidative damage of wheat plants in pots under drought. Plant Sci. 169, 313-321 (2005)

30. Kaya, C., Tuna, L. \& Higgs, D. Effect of silicon on plant growth and mineral nutrition of maize grown under water-stress conditions. J. Plant Nutr. 29 1469-1480 (2006).

31. Liu, P. et al. Aquaporin-mediated increase in root hydraulic conductance is involved in silicon-induced improved root water uptake under osmotic stress in Sorghum bicolor L. J. Exp. Bot. 65, 4747-4756 (2014).

32. Shi, Y. et al. Silicon enhances water stress tolerance by improving root hydraulic conductance in Solanum lycopersicum L. Front. Plant Sci. 7, 196 (2016).

33. Ma, J. F. Role of silicon in enhancing the resistance of plants to biotic and abiotic stresses. Soil Sci. Plant Nutr. 50, 11-18 (2004).

34. Gunes, A., Pilbeam, D. J., Inal, A. \& Coban, S. Influence of silicon on sunflower cultivars under drought stress, I: Growth, antioxidant mechanisms, and lipid peroxidation. Commun. Soil Sci. Plant Anal. 39, 1885-1903 (2008).

35. Shen, $X$. et al. Silicon effects on photosynthesis and antioxidant parameters of soybean seedlings under drought and ultraviolet-B radiation. J. Plant Physiol. 167, 1248-1252 (2010).

36. Farooq, M. A. et al. Alleviation of cadmium toxicity by silicon is related to elevated photosynthesis, antioxidant enzymes; suppressed cadmium uptake and oxidative stress in cotton. Ecotox. Environ. Safe. 96, 242-249 (2013).

37. Helaly, M. N., El-Hoseiny, H., El-Sheery, N. I., Rastogi, A. \& Kalaji, H. M. Regulation and physiological role of silicon in alleviating drought stress of mango. Plant Physiol. Biochem. 118, 31-44 (2017).

38. Habibi, G. Silicon supplementation improves drought tolerance in canola plants. Russ. J. Plant Physiol. 61, 784-791 (2014).

39. Thorne, S. J., Hartley, S. E. \& Maathuis, F. J. M. The effect of silicon on osmotic and drought stress tolerance in wheat landraces. Plants 10, 814 (2021).

40. Katz, O. Beyond grasses: the potential benefits of studying silicon accumulation in non-grass species. Front. Plant Sci. 5, 376 (2014).

41. Shi, Y. et al. Silicon improves seed germination and alleviates oxidative stress of bud seedlings in tomato under water deficit stress. Plant Physiol. Biochem. 78, 27-36 (2014)

42. Ghareeb, H. et al. Transcriptome of silicon-induced resistance against Ralstonia solanacearum in the silicon non-accumulator tomato implicates priming effect. Physiol. Mol. Plant P. 75, 83-89 (2011).

43. Hodson, M. J., White, P. J., Mead, A. \& Broadley, M. R. Phylogenetic variation in the silicon composition of plants. Ann. Bot. -Lond. 96, 1027-1046 (2005).

44. Hameed, A., Sheikh, M. A., Jamil, A. \& Basra, S. M. A. Seed priming with sodium silicate enhances seed germination and seedling growth in wheat (Triticum aestivum L.) under water deficit stress induced by polyethylene glycol. Pak. J. Life Soc. Sci. 11, 19-24 (2013).

45. Zargar, S. M. \& Agnihotri, A. Impact of silicon on various agro-morphological and physiological parameters in maize and revealing its role in enhancing water stress tolerance. Emir. J. Food Agr. 25, 138-141 (2013).
46. Biju, S., Fuentes, S. \& Gupta, D. Silicon improves seed germination and alleviates drought stress in lentil crops by regulating osmolytes, hydrolytic enzymes and antioxidant defense system. Plant Physiol. Biochem. 119 250-264 (2017).

47. Zia, Z. et al. Effect of water management and silicon on germination, growth, phosphorus and arsenic uptake in rice. Ecotox. Environ. Safe. 144, 11-18 (2017).

48. Chen, W., Yao, X., Cai, K. \& Chen, J. Silicon alleviates drought stress of rice plants by improving plant water status, photosynthesis and mineral nutrient absorption. Biol. Trace Elem. Res. 142, 67-76 (2011).

49. Hattori, T. et al. Silicon-induced changes in viscoelastic properties of sorghum root cell walls. Plant Cell Physiol. 44, 743-749 (2003).

50. Emam, M. M., Khattab, H. E., Helal, N. M. \& Deraz, A. E. Effect of selenium and silicon on yield quality of rice plant grown under drought stress. Aust. J. Crop Sci. 8, 596-605 (2014).

51. Javot, H. \& Maurel, C. The role of aquaporins in root water uptake. Ann. Bot. -Lond. 90, 301-313 (2002).

52. Hattori, T. et al. Silicon application by sorghum through the alleviation of stress-induced increase in hydraulic resistance. J. Plant Nutr. 31, 1482-1495 (2008).

53. Yin, L. et al. Silicon-mediated changes in polyamine and 1aminocyclopropane-1-carboxylic acid are involved in silicon-induced drought resistance in Sorghum bicolor L. Plant Physiol. Biochem. 80 268-277 (2014)

54. Lux, A., Luxová, M., Hattori, T., Inanaga, S. \& Sugimoto, Y. Silicification in sorghum (Sorghum bicolor) cultivars with different drought tolerance. Physiol. Plant. 115, 87-92 (2002).

55. Fleck, A. T. et al. Silicon enhances suberization and lignification in roots of rice (Oryza sativa). J. Exp. Bot. 62, 2001-2011 (2010).

56. Fleck, A. T. et al. Silicon promotes exodermal casparian band formation in siaccumulating and si-excluding species by forming phenol complexes. PLoS ONE 10, e0138555 (2015).

57. Lux, A. et al. Silicification of root tissues. Plants 9, 111 (2020).

58. Soukup, M. et al. Formation of silica aggregates in sorghum root endodermis is predetermined by cell wall architecture and development. Ann. Bot. -Lond. 120, 739-753 (2017).

59. Sonobe, K. et al. Diurnal variations in photosynthesis, stomatal conductance and leaf water relation in sorghum grown with or without silicon under water stress. J. Plant Nutr. 32, 433-442 (2009).

60. Sharp, R. E., Silk, W. K. \& Hsiao, T. C. Growth of the maize primary root at low water potentials: I. Spatial distribution of expansive growth. Plant Physiol. $\mathbf{8 7}$ 50-57 (1988).

61. Blum, A. Osmotic adjustment is a prime drought stress adaptive engine in support of plant production. Plant Cell Environ. 40, 4-10 (2017).

62. Morgan, J. M. Osmoregulation and water stress in higher plants. Annu. Rev. Plant Physiol. 35, 299-319 (1984).

63. Hare, P. \& Cress, W. Metabolic implications of stress-induced proline accumulation in plants. Plant Growth Regul. 21, 79-102 (1997).

64. Ashraf, M. \& Foolad, M. Roles of glycine betaine and proline in improving plant abiotic stress resistance. Environ. Exp. Bot. 59, 206-216 (2007)

65. Hsiao, T. C. \& Xu, L. K. Sensitivity of growth of roots versus leaves to water stress: biophysical analysis and relation to water transport. J. Exp. Bot. $\mathbf{5 1}$ 1595-1616 (2000)

66. Sonobe, K. et al. Effect of silicon application on sorghum root responses to water stress. J. Plant Nutr. 34, 71-82 (2010).

67. Crusciol, C. A., Pulz, A. L., Lemos, L. B., Soratto, R. P. \& Lima, G. P. Effects of silicon and drought stress on tuber yield and leaf biochemical characteristics in potato. Crop Sci. 49, 949-954 (2009).

68. Zhu, Y. et al. The regulatory role of silicon on carbohydrate metabolism in Cucumis sativus L. under salt stress. Plant Soil 406, 231-249 (2016).

69. Zhu, Z., Wei, G., Li, J., Qian, Q. \& Yu, J. Silicon alleviates salt stress and increases antioxidant enzymes activity in leaves of salt-stressed cucumber (Cucumis sativus L.). Plant Sci. 167, 527-533 (2004)

70. Gunes, A., Pilbeam, D. J., Inal, A., Bagci, E. G. \& Coban, S. Influence of silicon on antioxidant mechanisms and lipid peroxidation in chickpea (Cicer arietinum L.) cultivars under drought stress. J. Plant Interact. 2, 105-113 (2007).

71. Steudle, E. Water uptake by roots: effects of water deficit. J. Exp. Bot. 51, 1531-1542 (2000).

72. Wang, S. et al. Silicon enhanced salt tolerance by improving the root water uptake and decreasing the ion toxicity in cucumber. Front. Plant Sci. 6, 759 (2015). 
73. Zhu, Y. X. et al. Silicon improves salt tolerance by increasing root water uptake in Cucumis sativus L. Plant Cell Rep. 34, 1629-1646 (2015).

74. Hattori, T., Ishii, K., An, P. \& Inanaga, S. Growth enhancement of rye by silicon application under two different soil water regimes. J. Plant Nutr. 32, 187-196 (2009).

75. Hattori, T. et al. Short term stomatal responses to light intensity changes and osmotic stress in sorghum seedlings raised with and without silicon. Environ. Exp. Bot. 60, 177-182 (2007).

76. Benabdellah, K., Ruiz-Lozano, J. M. \& Aroca, R. Hydrogen peroxide effects on root hydraulic properties and plasma membrane aquaporin regulation in Phaseolus vulgaris. Plant Mol. Biol. 70, 647 (2009).

77. Razem, F. A. \& Bernards, M. A. Hydrogen peroxide is required for poly(phenolic) domain formation during wound-induced suberization. J. Agr. Food Chem. 50, 1009-1015 (2002).

78. Chrispeels, M. J. \& Maurel, C. Aquaporins: the molecular basis of facilitated water movement through living plant cells? Plant Physiol. 105, 9 (1994).

79. Kruse, E., Uehlein, N. \& Kaldenhoff, R. The aquaporins. Genome Biol. 7, 206 (2006)

80. Hove, R. M. \& Bhave, M. Plant aquaporins with non-aqua functions: deciphering the signature sequences. Plant Mol. Biol. 75, 413-430 (2011).

81. Wang, R. et al. Exploring the roles of aquaporins in plant-microbe interactions. Cells 7, 267 (2018).

82. Wang, $M$. et al. The interactions of aquaporins and mineral nutrients in higher plants. Int. J. Mol. Sci. 17, 1229 (2016).

83. Maurel, C., Verdoucq, L., Luu, D. T. \& Santoni, V. Plant aquaporins: membrane channels with multiple integrated functions. Annu. Rev. Plant Biol. 59, 595-624 (2008).

84. Kaldenhoff, R. et al. Aquaporins and plant water balance. Plant Cell Environ. 31, 658-666 (2008)

85. Steudle, E. \& Peterson, C. A. How does water get through roots? J. Exp. Bot. 49, 775-788 (1998)

86. Chaumont, F. \& Tyerman, S. D. Aquaporins: highly regulated channels controlling plant water relations. Plant Physiol. 164, 1600-1618 (2014).

87. Vandeleur, R. K. et al. The role of plasma membrane intrinsic protein aquaporins in water transport through roots: diurnal and drought stress responses reveal different strategies between isohydric and anisohydric cultivars of grapevine. Plant Physiol. 149, 445-460 (2009).

88. Ma, J. F. et al. A silicon transporter in rice. Nature 440, 688 (2006).

89. Chiba, Y., Mitani, N., Yamaji, N. \& Ma, J. F. HvLsi1 is a silicon influx transporter in barley. Plant J. 57, 810-818 (2009).

90. Deshmukh, R. \& Belanger, R. R. Molecular evolution of aquaporins and silicon influx in plants. Funct. Ecol. 30, 1277-1285 (2016).

91. Liu, P. et al. Enhanced root hydraulic conductance by aquaporin regulation accounts for silicon alleviated salt-induced osmotic stress in Sorghum bicolor L. Environ. Exp. Bot. 111, 42-51 (2015).

92. Chen, D., Wang, S., Yin, L. \& Deng, X. How does silicon mediate plant water uptake and loss under water deficiency? Front. Plant Sci. 9, 281 (2018).

93. Gao, X., Zou, C., Wang, L. \& Zhang, F. Silicon improves water use efficiency in maize plants. J. Plant Nutr. 27, 1457-1470 (2005).

94. Ahmed, M., Qadeer, U. \& Aslam, M. A. Silicon application and drought tolerance mechanism of sorghum. Afr. J. Agr. Res. 6, 594-607 (2011).

95. Cachorro, P., Ortiz, A. \& Cerdá, A. Implications of calcium nutrition on the response of Phaseolus vulgaris L. to salinity. Plant Soil 159, 205-212 (1994).

96. Marschner, P. Marschner's Mineral nutrition of higher plants. 3rd edn (Academic Press, 2012).

97. Pavlovic, J. et al. Silicon alleviates iron deficiency in cucumber by promoting mobilization of iron in the root apoplast. N. Phytol. 198, 1096-1107 (2013).

98. Liang, Y. Effects of silicon on enzyme activity and sodium, potassium and calcium concentration in barley under salt stress. Plant Soil 209, 217 (1999).

99. Che, J., Yamaji, N., Shao, J. F., Ma, J. F. \& Shen, R. F. Silicon decreases both uptake and root-to-shoot translocation of manganese in rice. J. Exp. Bot. 67, 1535-1544 (2016).

100. Shao, J. F., Che, J., Yamaji, N., Shen, R. F. \& Ma, J. F. Silicon reduces cadmium accumulation by suppressing expression of transporter genes involved in cadmium uptake and translocation in rice. J. Exp. Bot. 68, 5641-5651 (2017).

101. Hernandez-Apaolaza, L. Can silicon partially alleviate micronutrient deficiency in plants? A review. Planta 240, 447-458 (2014).

102. Gao, X., Zou, C., Wang, L. \& Zhang, F. Silicon decreases transpiration rate and conductance from stomata of maize plants. J. Plant Nutr. 29, 1637-1647 (2006)
103. Küpfer, C. \& Kahnt, G. Effects of the application of amorphous silica on transpiration and photosynthesis of soybean plants under varied soil and relative air humidity conditions. J. Agron. Crop Sci. 168, 318-325 (1992).

104. Ma, C. C., Li, Q. F., Gao, Y. B. \& Xin, T. R. Effects of silicon application on drought resistance of cucumber plants. Soil Sci. Plant Nutr. 50, 623-632 (2004).

105. Liu, H. X. \& Guo, Z. G. Forage Yield and water use efficiency of alfalfa applied with silicon under water deficit conditions. Philipp. Agric. Sci. 96, 370-376 (2013).

106. Agarie, S., Uchida, H., Agata, W., Kubota, F. \& Kaufman, P. B. Effects of silicon on transpiration and leaf conductance in rice plants (Oryza sativa L.). Plant Prod. Sci. 1, 89-95 (1998).

107. Savant, N., Snyder, G. \& Datnoff, L. Silicon management and sustainable rice production. Adv. Agron. 58, 151-199 (1996).

108. Savant, N. K., Korndörfer, G. H., Datnoff, L. E. \& Snyder, G. H. Silicon nutrition and sugarcane production: a review. J. Plant Nutr. 22, 1853-1903 (1999)

109. Gong, H., Chen, K., Chen, G., Wang, S. \& Zhang, C. Effects of silicon on growth of wheat under drought. J. Plant Nutr. 26, 1055-1063 (2003).

110. Hattori, T. et al. Application of silicon enhanced drought tolerance in Sorghum bicolor. Physiol. Plant. 123, 459-466 (2005).

111. Zhu, Y. \& Gong, H. Beneficial effects of silicon on salt and drought tolerance in plants. Agron. Sustain. Dev. 34, 455-472 (2014).

112. Ueno, O. \& Agarie, S. Silica deposition in cell walls of the stomatal apparatus of rice leaves. Plant Prod. Sci. 8, 71-73 (2005)

113. Savvas, D. \& Ntatsi, G. Biostimulant activity of silicon in horticulture. Sci. Hortic. 196, 66-81 (2015).

114. Pereira, T. S. et al. Positive interference of silicon on water relations, nitrogen metabolism, and osmotic adjustment in two pepper (Capsicum annuum) cultivars under water deficit. Aust. J. Crop Sci. 7, 1064 (2013).

115. Zhang, Q. et al. Silicon alleviation of cadmium toxicity in mangrove (Avicennia marina) in relation to cadmium compartmentation. J. Plant Growth Regul. 33, 233-242 (2014).

116. Zhang, C. et al. Foliar application of Sili- $K^{\circledR}$ increases chestnut (Castanea spp) growth and photosynthesis, simultaneously increasing susceptibility to water deficit. Plant Soil 365, 211-225 (2013).

117. Hattori, T., Sonobe, K., Inanaga, S., An, P. \& Morita, S. Effects of silicon on photosynthesis of young cucumber seedlings under osmotic stress. J. Plant Nutr. 31, 1046-1058 (2008).

118. Savvas, D. et al. Interactions between silicon and $\mathrm{NaCl}$-salinity in a soilless culture of roses in greenhouse. Eur. J. Hortic. Sci. 72, 73 (2007).

119. Fauteux, F., Chain, F., Belzile, F., Menzies, J. G. \& Bélanger, R. R. The protective role of silicon in the Arabidopsis-powdery mildew pathosystem. P. Natl Acad. Sci. USA 103, 17554-17559 (2006).

120. Brunings, $A$. et al. Differential gene expression of rice in response to silicon and rice blast fungus Magnaporthe oryzae. Ann. Appl. Biol. 155, 161-170 (2009).

121. Kim, Y. H. et al. Silicon application to rice root zone influenced the phytohormonal and antioxidant responses under salinity stress. J. Plant Growth Regul. 33, 137-149 (2014)

122. Hamayun, M. et al. Silicon alleviates the adverse effects of salinity and drought stress on growth and endogenous plant growth hormones of soybean (Glycine max L.). Pak. J. Bot. 42, 1713-1722 (2010).

123. Lee, S. C. \& Luan, S. ABA signal transduction at the crossroad of biotic and abiotic stress responses. Plant Cell Environ. 35, 53-60 (2012).

124. Hosseini, S. A. et al. Induction of barley silicon transporter HVLsi1 and HVLsi2, increased silicon concentration in the shoot and regulated starch and ABA homeostasis under osmotic stress and concomitant potassium deficiency. Front. Plant Sci. 8, 1359 (2017).

125. Kim, Y. H. et al. Regulation of jasmonic acid biosynthesis by silicon application during physical injury to Oryza sativa L. J. Plant Res. 127, 525-532 (2014)

126. Manivannan, A. \& Ahn, Y. K. Silicon regulates potential genes involved in major physiological processes in plants to combat stress. Front. Plant Sci. 8 , 1346 (2017).

127. Shetty, R. et al. Silicon-induced changes in antifungal phenolic acids, flavonoids, and key phenylpropanoid pathway genes during the interaction between miniature roses and the biotrophic pathogen Podosphaera pannosa. Plant Physiol. 157, 2194-2205 (2011). 
128. Song, A. et al. The role of silicon in enhancing resistance to bacterial blight of hydroponic- and soil-cultured rice. Sci. Rep. 6, 24640-24640 (2016).

129. Dubouzet, J. G. et al. OsDREB genes in rice, Oryza sativa L., encode transcription activators that function in drought-, high-salt- and coldresponsive gene expression. Plant J. 33, 751-763 (2003).

130. Hussain, S. S., Kayani, M. A. \& Amjad, M. Transcription factors as tools to engineer enhanced drought stress tolerance in plants. Biotechnol. Progr. 27, 297-306 (2011).

131. Egert, M. \& Tevini, M. Influence of drought on some physiological parameters symptomatic for oxidative stress in leaves of chives (Allium schoenoprasum). Environ. Exp. Bot. 48, 43-49 (2002).

132. Smirnoff, N. The role of active oxygen in the response of plants to water deficit and desiccation. N. Phytol. 125, 27-58 (1993).

133. Boursiac, $Y$. et al. The response of Arabidopsis root water transport to a challenging environment implicates reactive oxygen species-and phosphorylation-dependent internalization of aquaporins. Plant Signal. Behav 3, 1096-1098 (2008).

134. Pei, Z. F. et al. Silicon improves the tolerance to water-deficit stress induced by polyethylene glycol in wheat (Triticum aestivum L.) Seedlings. J. Plant Growth Regul. 29, 106-115 (2009).

135. Gong, H., Chen, K., Zhao, Z., Chen, G. \& Zhou, W. Effects of silicon on defense of wheat against oxidative stress under drought at different developmental stages. Biol. Plant. 52, 592-596 (2008).

136. Ahmad, P., Jaleel, C. A., Salem, M. A., Nabi, G. \& Sharma, S. Roles of enzymatic and nonenzymatic antioxidants in plants during abiotic stress. Crit. Rev. Biotechnol. 30, 161-175 (2010).

137. Ma, D. et al. Silicon application alleviates drought stress in wheat through transcriptional regulation of multiple antioxidant defense pathways. J. Plant Growth Regul. 35, 1-10 (2016). 